\title{
Ginsenoside Rb1 Reduces Nitric Oxide Production via Inhibition of Nuclear Factor-kB Activation in Interleukin-1 $\beta$ - Stimulated SW1353 Chondrosarcoma Cells
}

\author{
Ping Jia ${ }^{1 *}$, Gang Chen ${ }^{2}$, Rongheng $\mathrm{Li}^{1}$, Xiaofeng Rong ${ }^{1}$, Guoqing Zhou ${ }^{1}$ and $\mathrm{Yu}$ \\ Zhong ${ }^{1}$ \\ ${ }^{1}$ Department of Combination of Chinese and Western Medicine, the First Affiliated Hospital of Chongqing Medical University, \\ Chongqing 400016, ${ }^{2}$ School of Environmental and Biological Engineering, Chongqing Technology and Business University, \\ Chongqing 400067, PR China
}

*For correspondence: Email: jiap008@hotmail.com; Tel/Fax: (+86) 23-8901-2864

\begin{abstract}
Purpose: To investigate the effect and the potential mechanisms of ginsenoside Rb1 on nitric oxide (NO) production in chondrocytes.

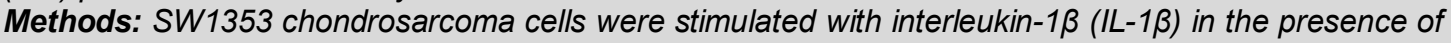
20, 40, $80 \mu \mathrm{M}$ ginsenoside Rb1. NO concentration was assessed by the Griess reaction. Expression of inducible nitric oxide synthase (iNOS), content of inhibitor of NF-KB (IKB) $\alpha$ and nuclear level of nuclear factor (NF)-KB p65 were determined by Western blot. DNA binding activity of NF-kB was evaluated with Trans $A M^{\text {TM }}$ kit for NF-KB p65.

Results: Ginsenoside Rb1 (40 and $80 \mu \mathrm{M})$ significantly decreased NO level by $24(p<0.05)$ and $46 \%$ $(p<0.01)$, as well as iNOS protein expression by 40 and $55 \%(p<0.01)$, respectively, in IL-1 $\beta$ stimulated SW1353 cells. Ginsenoside Rb1 (40 and $80 \mu \mathrm{M})$ also markedly elevated IKBa protein content by 200 and $260 \%(p<0.01)$, reduced the nuclear level of p65 protein by 30 and $40 \%(p<0.01)$, as well as decreased the DNA binding activity of NF-KB by 40 and $50 \%$ (both $p<0.01$ ), respectively, in IL$1 \beta$-stimulated SW1353 cells.

Conclusion: These results suggest that ginsenoside Rb1 inhibits IL-1 $\beta$-induced NO production through downregulation of NF-KB-dependent iNOS expression in chondrocytes, and also underlines the potential mechanisms of ginseng activity in OA treatment of TCM.
\end{abstract}

Keywords: Ginsenoside Rb1, Nitric oxide, Nuclear factor-kB, Chondrocytes, Osteoarthritis

Tropical Journal of Pharmaceutical Research is indexed by Science Citation Index (SciSearch), Scopus, International Pharmaceutical Abstract, Chemical Abstracts, Embase, Index Copernicus, EBSCO, African Index Medicus, JournalSeek, Journal Citation Reports/Science Edition, Directory of Open Access Journals (DOAJ), African Journal Online, Bioline International, Open-J-Gate and Pharmacy Abstracts

\section{INTRODUCTION}

Osteoarthritis $(\mathrm{OA})$ is one of the most common chronic diseases affecting the elderly and is characterized by the abnormal degradation of the cartilage matrix and immoderate deposition of subchondral bone matrix. A growing body of evidence supports the fact that nitric oxide (NO) plays a role in the pathological development of OA [1]. Osteoarthritic joints exhibited elevated
NO production as well as increased amounts of other inflammatory mediators [2]. OA patients exhibited markers of enhanced NO production in their urine, serum, and synovial fluid [3]. In inflammatory reactions, $\mathrm{NO}$ is generated principally by inducible NO synthase (iNOS). Chondrocytes, the cellular occupants of cartilage and thus central to maintaining the integrity of the matrix, are the main cellular source of $\mathrm{NO}$ and iNOS generation in OA [4]. NO is considered as 
a pro-inflammatory agent as well as a potent catabolic mediator in OA since it promotes the production of inflammatory cytokines [5], activates matrix metalloproteinases [6] and inhibits the synthesis of collagen and proteoglycan [7].

Nuclear factor-kB (NF-kB) is the key transcription factor regulating iNOS gene expression in inflammatory conditions [8]. NF-KB exists as a homo- or hetero-dimeric form of Rel family proteins which include p65, p50, p52, RelB and cRel. The complex between p65/p50 is the predominant heterodimer. NF-KB is sequestered in the cytoplasm where it is bound to inhibitors of

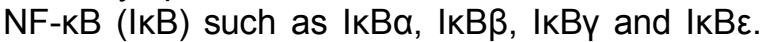
Activation of NF-kB is dependent on the phosphorylation and degradation of $1 \mathrm{kB}$. Free NF-KB can then translocate to the nucleus, bind to the specific DNA binding sites, and initiate expression of target genes including iNOS, interleukin-1 $\beta$ (IL-1 $\beta$ ) and tumor necrosis factor- $\alpha$ (TNF- $\alpha$ ) [9]. Concurrently, IL-1 $\beta$ and TNF- $\alpha$ are also the potent inducers for NF-KB activation [10].

Principal treatments for $\mathrm{OA}$ are mainly palliative for symptoms of dyskinesia and joint pain [11]. Use of ginseng dates back more than 2000 years in China, and is one of the most popular Chinese materia medica in traditional Chinese medicine (TCM) formulas for OA treatment [12]. Ginsenoside Rb1, a principle active constituent of ginseng, has been reported to have antiinflammatory action. Ginsenoside Rb1 inhibited the expression of TNF- $\alpha, \quad \mathrm{IL}-1 \beta$ and IL- 6 in lipopolysaccharide (LPS) -stimulated murine peritoneal macrophages [13]. Although release of $\mathrm{NO}$ by ginsenoside Rb1 may underlie the cardiovascular protection [14], the effects and mechanisms of ginsenoside $\mathrm{Rb} 1$ on $\mathrm{NO}$ production by chondrocytes during inflammatory conditions are not clear. Thus, the purpose of this study was to investigate the effect of ginsenoside $\mathrm{Rb} 1$ on $\mathrm{NO}$ production, iNOS expression and NF-kB activation in IL-1 $\beta$ stimulated SW1353 chondrosarcoma cells.

\section{EXPERIMENTAL}

\section{Chemicals and reagents}

All chemicals and reagents were purchased from Sigma-Aldrich (St Louis, MO, USA) unless otherwise specified. Ginsenoside Rb1 was purchased from the National Institute for the Control of Pharmaceutical and Biological Products (Beijing, China). Recombinant human IL-1 $\beta$ was purchased from R\&D System (Minneapolis, Minnesota, USA). Dulbecco's modified Eagle's medium (DMEM) and fetal bovine serum (FBS) were purchased from Gibco BRL (Grand Island, NY, USA). Antibodies against iNOS, IkBa, NF-kB p65, $\beta$-actin, and lamin B1 were purchased from Santa Cruz (Santa Cruz, CA, USA). ECL Western Blot detection system and polyvinylidene difluoride (PVDF) membranes were purchased from Millipore (Bedford, MA, USA). Trans AM $^{\mathrm{TM}}$ kit for p65 was purchased from Active Motif (Carlsbad, CA, USA). NO detection kit based on the Griess reaction was purchased from Nanjing Jiancheng Bioengineering Institute (Nanjing, Jiangsu, China).

\section{Cell culture}

SW1353 human chondrosarcoma cell line purchased from the American Type Culture Collection were cultured in DMEM with $10 \%$ FBS, $100 \mathrm{U} / \mathrm{mL}$ penicillin and $100 \mu \mathrm{g} / \mathrm{mL}$ streptomycin at $37{ }^{\circ} \mathrm{C}$ in humidified air with $5 \%$ $\mathrm{CO}_{2}$. Cells were cultured in DMEM with $1 \% \mathrm{FBS}$ for $24 \mathrm{~h}$, and then stimulated with $10 \mathrm{ng} / \mathrm{mL}$ IL-1 $\beta$ for indicated time periods. The supernatant or the cell layer was then collected for further analyses.

\section{MTT assay}

MTT assay was used to evaluate the cytotoxic effect. Approximately $1 \times 10^{4} \mathrm{SW} 1353$ cells/well were incubated in a total volume of $200 \mu \mathrm{l}$ in 96well plates with or without ginsenoside Rb1. After an incubation period of $24 \mathrm{~h}$, MTT was added for $4 \mathrm{~h}$ at the final concentration of $0.5 \mathrm{mg} / \mathrm{ml}$. Subsequently, the culture medium was removed and after dissolving the formazan crystals in dimethyl sulfoxide (DMSO), plates were read immediately at $570 \mathrm{~nm}$ using an absorbance plate reader (Bio-Rad, USA). Wells containing incubation media without cells were used as control. SW1353 cells treated with vehicle only were defined as $100 \%$ viable. Cell survival was defined as the growth of treated cells compared with untreated cells.

\section{NO measurement}

NO production in the supernatants was analyzed using a commercial NO detection kit based on the Griess reaction according to the manufacturer's instructions.

\section{Preparation of protein extracts (total and nuclear)}

The total cellular proteins were extracted by radio-immunoprecipitation assay (RIPA) lysis buffer (50 mM Tris-HCl, pH 8.0, 150 mM NaCl, 1 $\%$ NP-40, $0.1 \%$ Sodium dodecyl sulfate (SDS), 
$0.5 \%$ sodium deoxycholate) and ethylene diamine tetraacetic acid (EDTA)-free protease inhibitor cocktail (Roche). To separate the nuclear proteins, cells were suspended in $250 \mu \mathrm{l}$ of buffer A (10 mM hydroxyethyl piperazineethanesulfonic acid (HEPES), $\mathrm{pH} 7.9$, $1.5 \mathrm{mM} \mathrm{MgCl}_{2}, 10 \mathrm{mM} \mathrm{KCl}, 0.1 \mathrm{mM}$ EDTA, 0.1 $\mathrm{mM}$ ethylene glycol tetraacetic acid (EGTA), 1 $\mathrm{mM}$ dithiothreitol (DTT), $0.5 \%$ NP-40 and EDTAfree protease inhibitor cocktail), followed by centrifugation at $10000 \mathrm{~g}$ for $10 \mathrm{~min}$ at $4{ }^{\circ} \mathrm{C}$. The pelleted nucleic protein extracts were resuspended in $50 \mu$ l of buffer $B$ (20 mM Hepes, $\mathrm{pH}$ 7.9, $400 \mathrm{mM} \mathrm{NaCl}, 1 \mathrm{mM}$ EDTA, $1 \mathrm{mM}$ EGTA, $1 \mathrm{mM}$ DTT, $1 \mathrm{mM} \mathrm{NaF}, 1 \mathrm{mM}$ sodium orthovanadate, and EDTA-free protease inhibitor cocktail) and centrifuged at $10000 \mathrm{~g}$ for $10 \mathrm{~min}$ at $4{ }^{\circ} \mathrm{C}$. The quantity of proteins was measured using the Lowry method and all the protein samples were stored at $-70^{\circ} \mathrm{C}$.

\section{Western blot analysis}

Equal amounts of total (for iNOS, I $\mathrm{kB} \alpha$ and $\beta$ actin) or nuclear (for P65 and lamin B1) protein samples were separated by $10 \%$ SDSpolyacrylamide gelelectrophoresis (PAGE), and then transferred onto PVDF membranes. After blocking with $5 \%$ nonfat milk in Tris-buffered saline with Tween (TBST) buffer (20 mM Tris, pH 7.6, $137 \mathrm{mM} \mathrm{NaCl}, 0.1 \%$ Tween 20) for $1 \mathrm{~h}$ at room temperature, PVDF membranes were incubated with the primary antibody at $4{ }^{\circ} \mathrm{C}$ overnight and subsequently with peroxidaseconjugated second antibody at room temperature for $1 \mathrm{~h}$. The protein bands were detected with ECL. Signals were detected and analyzed using the ChemiDoc XRS imaging system (Bio-Rad, USA).

\section{NF-KB DNA-binding activity}

The binding ability of NF-KB to DNA consensus sequences was measured by ELISA in nuclear protein extracts using the Trans $\mathrm{AM}^{\mathrm{TM}}$ kit for $\mathrm{p} 65$ following the manufacturer's recommendations. Briefly, nuclear extracts $(5 \mu \mathrm{g})$ were added to the wells followed by the primary antibody against p65 and the horseradish peroxidase-conjugated secondary antibody. The optical density was measured at $450 \mathrm{~nm}$ with an absorbance plate reader (Bio-Rad, USA).

\section{Statistical analysis}

Results are reported as mean \pm SD. Data were analyzed by one-way analysis of variance (ANOVA) followed by Dunnet test. Differences were considered statistically significant when $p<$ 0.05 .

\section{RESULTS}

\section{Effect of ginsenoside Rb1 on NO production}

We first tested whether ginsenoside $\mathrm{Rb} 1$ had any effect on IL-1 $\beta$-induced NO production. Basal levels of $\mathrm{NO}$ in SW1353 cells were low without $\mathrm{IL}-1 \beta$ stimulation. The concentration of $\mathrm{NO}$ increased more than 15-fold $(p<0.01)$ in presence of IL-1 $\beta$ after $24 \mathrm{~h}$ compared to baseline levels (Fig 1A, B). This effect was abrogated in a concentration-dependent manner when SW1353 cells were coincubated with various concentrations of ginsenoside $\mathrm{Rb} 1$. Ginsenoside $\mathrm{Rb} 1$ at $40 \mu \mathrm{M}$ and $80 \mu \mathrm{M}$ decreased IL-1 $\beta$-induced NO production by approximately $24 \%(p<0.05)$ and $46 \%(p<0.01)$, respectively (Fig 1A). Ginsenoside Rb1 at $20 \mu \mathrm{M}$ did not show any effect on IL-1 $\beta$-induced NO production in SW1353 cells (Fig 1A). Ginsenoside Rb1 at the concentrations used in this study did not appear to be cytotoxic to the SW1353 cells (Fig 1B).
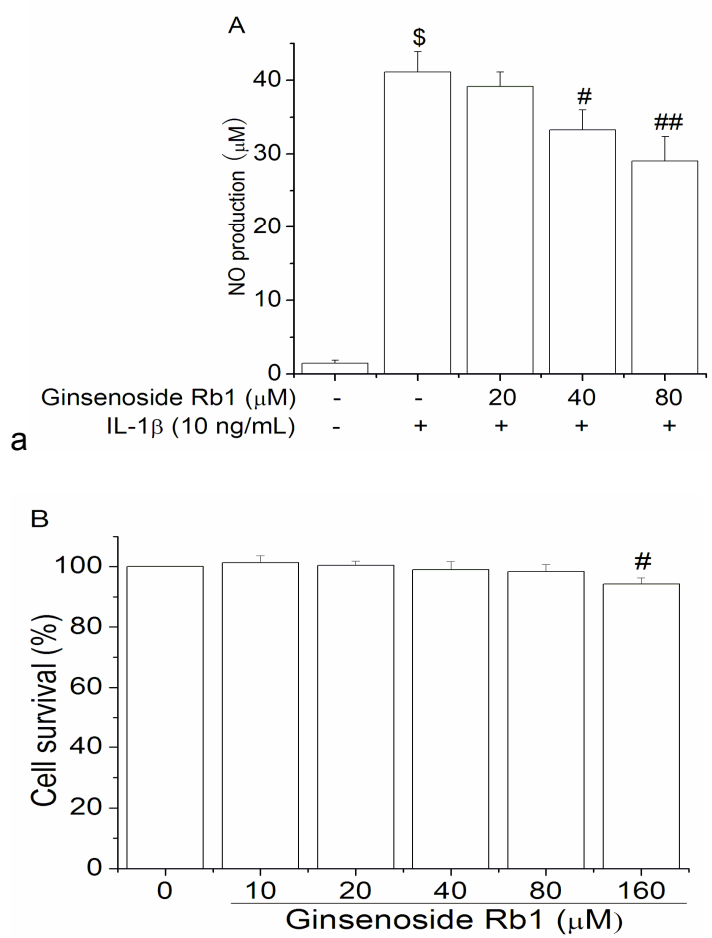

Figure 1: Effect of ginsenoside Rb1 on NO production in IL-1ß-induced SW1353 cells. SW1353 cells were pre-treated with ginsenoside Rb1 $(20,40,80 \mu \mathrm{M})$ for 2 $\mathrm{h}$ and stimulated with $10 \mathrm{ng} / \mathrm{mL} \mathrm{IL}-1 \beta$ for $24 \mathrm{~h}$. (A) Secreted $N O$ in the cell-free culture media was measured by Greiss reaction. (B) MTT assay was performed to evaluate cytotoxicity. Three independent experiments performed in duplicate; values are mean \pm SD. In Figure $1 A,{ }^{\$} p<0.01$ vs. media alone-treated group, and ${ }^{\sharp} p<0.05$ or ${ }^{\# \#} p<0.01$ vs. IL- $1 \beta$ alone-treated group. In Figure 1B, ${ }^{\#} p<0.05$ vs. media alone-treated group. 


\section{Effect of ginsenoside Rb1 on iNOS expression}

Western blot analysis was carried out to investigate whether the inhibitory effect of ginsenoside $\mathrm{Rb} 1$ on $\mathrm{NO}$ production was due to its influence on iNOS synthesis, a dominant source of $\mathrm{NO}$ in inflammatory conditions. Expression of iNOS protein was not detectable in unstimulated SW1353 cells, but was considerably induced upon exposure to IL-1 $\beta$ alone (Fig 2A, B). Ginsenoside Rb1 decreased $\mathrm{IL}-1 \beta$-induced expression of iNOS protein in a concentration-dependent manner, corresponding to about $40 \%$ inhibition at $40 \mu \mathrm{M}, 55 \%$ at $80 \mu \mathrm{M}$ (both $p<0.01$, Fig 2B). Levels of iNOS protein were not significantly affected at $20 \mu \mathrm{M}$ ginsenoside Rb1 (Fig 2A, B).

\section{Effect of ginsenoside Rb1 on IKBa degradation}

Because the translocation of NF-KB to the nucleus depends on degradation of $I K B \alpha$, we investigated whether ginsenoside Rb1 could affect this process. Reduction of $I \mathrm{kBa}$ protein dramatically occurred within $30 \mathrm{~min}$ upon exposure to IL-1 $\beta$ alone ( $p<0.01$, Fig 3A, B). Ginsenoside Rb1 at $40 \mu \mathrm{M}$ and $80 \mu \mathrm{M}$ markedly promoted the content of IKBa protein in IL-1 $\beta$ induced SW 1353 cells by approximately $200 \%$ and $260 \%$, respectively (both $p<0.01$, Fig 3B). However, ginsenoside Rb1 at $20 \mu \mathrm{M}$ did not have a significant effect on IL-1 $\beta$-induced IKBa protein content (Fig 3A, B).

A
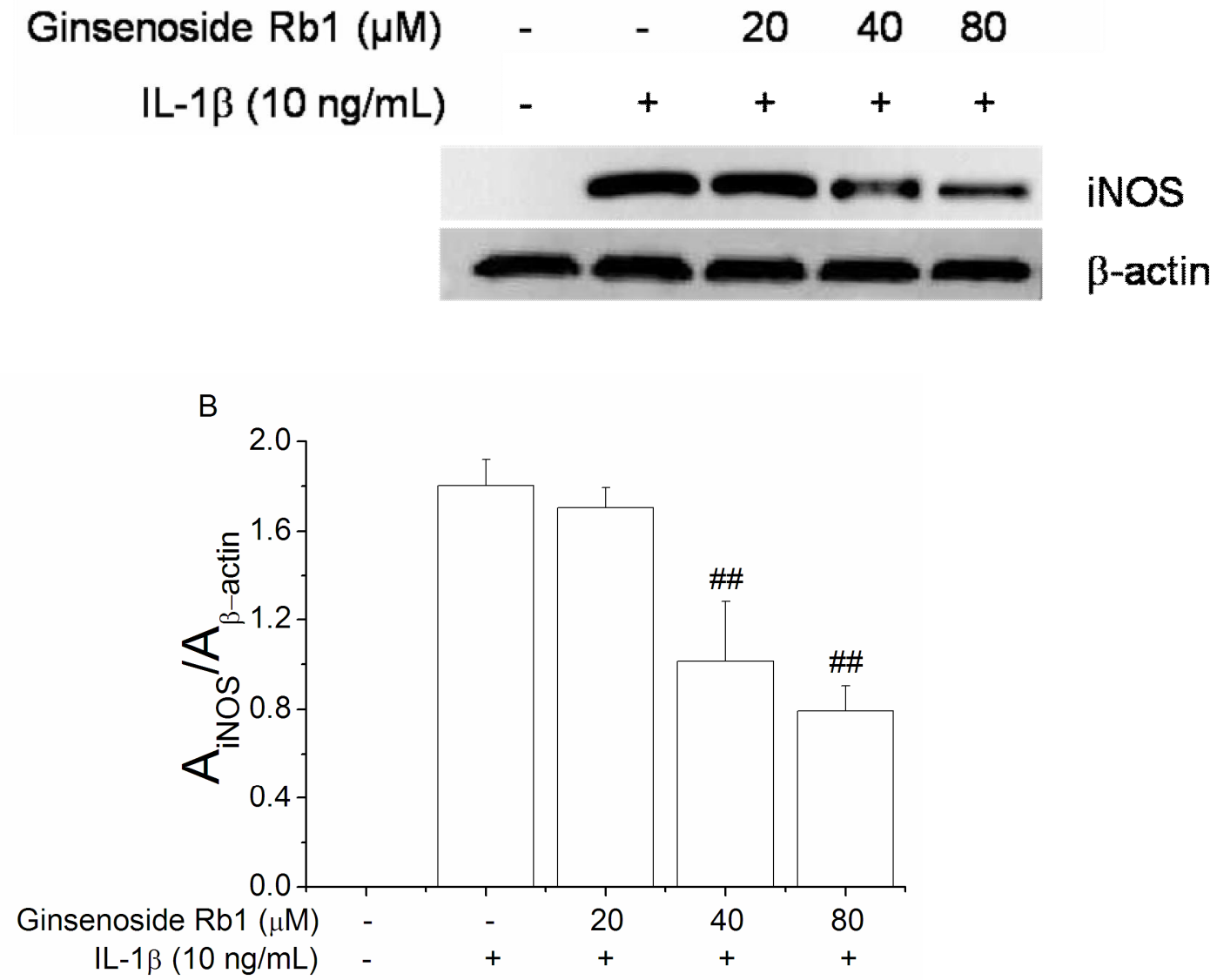

Figure 2: Effect of ginsenoside Rb1 on iNOS expression in IL-1 $\beta$-induced SW1353 cells. SW1353 cells were pretreated with ginsenoside $\operatorname{Rb} 1(20,40,80 \mu \mathrm{M})$ for $2 \mathrm{~h}$ and stimulated with $10 \mathrm{ng} / \mathrm{mL} \mathrm{IL}-1 \beta$ for $24 \mathrm{~h}$. (A) iNOS protein in the cell lysates was detected by Western blot; (B) Bar graphs showed quantitative evaluation of iNOS bands by densitometry. Three independent experiments performed in duplicate; values are mean \pm SD; ${ }^{\#} p<0.01$ vs. IL-1 $\beta$ alone-treated group 

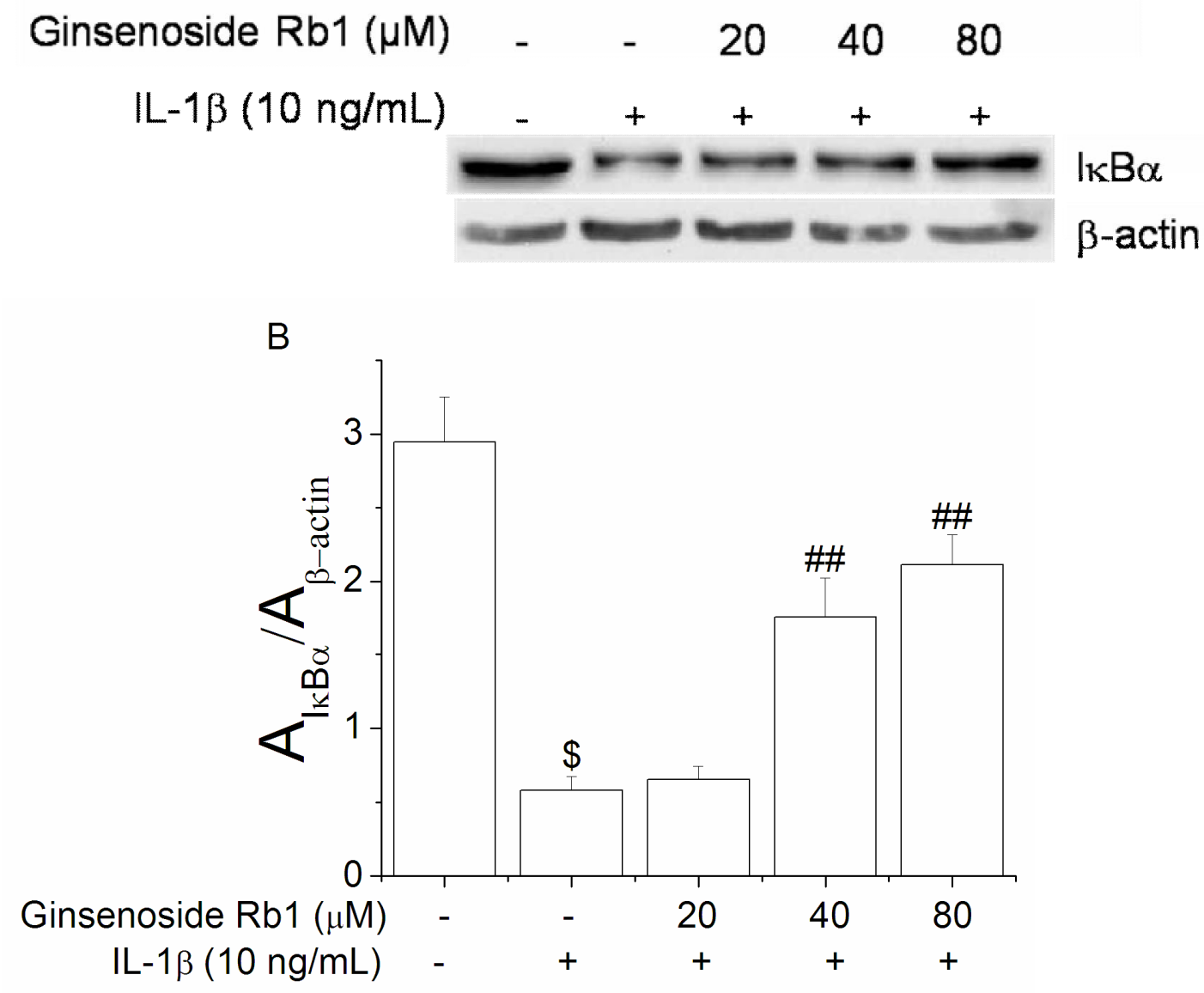

Figure 3: Effect of ginsenoside Rb1 on degradation of $I_{\kappa} B \alpha$ in IL-1 $\beta$-induced SW1353 cells. SW1353 cells were pre-treated with ginsenoside $\mathrm{Rb} 1(20,40,80 \mu \mathrm{M})$ for $2 \mathrm{~h}$ and stimulated with $10 \mathrm{ng} / \mathrm{mL} \mathrm{IL}-1 \beta$ for $30 \mathrm{~min}$. (A) I/Ba protein in the cell lysates was detected by Western blot; (B) Bar graphs showed quantitative evaluation of $I_{\kappa} B \alpha$ bands by densitometry. Three independent experiments performed in duplicate. Values are mean $\pm S D ;{ }^{\$} p<0.01$ vs. media alone-treated group; ${ }^{\# \#} p<0.01$ vs. IL-1 $\beta$ alone-treated group

\section{Effect of ginsenoside $\mathrm{Rb} 1$ on nuclear translocation of NF-KB p65}

To further determine whether ginsenoside $\mathrm{Rb} 1$ could modulate nuclear translocation of NF-KB, nuclear level of NF-KB p65 protein were examined in IL-1 $1 \beta$-stimulated SW1353 cells. Amounts of nuclear NF-KB p65 were markedly increased after stimulation with IL-1 $\beta$ alone for 1 h $(p<0.01$, Fig 4A, B). Ginsenoside Rb1 reduced amounts of nuclear NF-kB p65 in IL-1 $\beta$ stimulated SW1353 cells in a concentrationdependent manner, corresponding to approximate $30 \%$ inhibition at $40 \mu \mathrm{M}$ and $40 \%$ at $80 \mu \mathrm{M}$ (both $\mathrm{p}<0.01$, Fig 4B). However, $20 \mu \mathrm{M}$ ginsenoside $\mathrm{Rb} 1$ did not significantly affect amounts of nuclear NF-kB p65 in IL-1 $\beta$ stimulated SW1353 cells (Fig. 4A, B).

\section{Effect of ginsenoside Rb1 on DNA binding activity of NF-kB}

Activation of NF-KB is due to increased DNA binding after its dissociation from IKBa. Since the p65 subunit has potent transcriptional activation domains, we investigated whether ginsenoside $\mathrm{Rb} 1$ could modulate DNA binding activity of NFKB p65 in IL-1 $\beta$-stimulated SW1353 cells in an ELISA-based assay. Upon exposure to IL-1 $\beta$ alone, DNA binding activity of NF-KB p65 was significantly increased within $1 \mathrm{~h}(p<0.01$, Fig. $5)$. Ginsenoside Rb1 decreased IL-1 $\beta$-induced DNA binding activity of NF-KB p65 in a concentration-dependent manner, corresponding to approximately $40 \%$ inhibition at $40 \mu \mathrm{M}$ and 50 $\%$ at $80 \mu \mathrm{M}$ (both $p<0.01$, Fig. 5). Ginsenoside $\mathrm{Rb} 1$ at $20 \mu \mathrm{M}$ did not have a significantly effect on IL-1 $\beta$-induced DNA binding activity of NF-KB p65 (Fig. 5). 
A
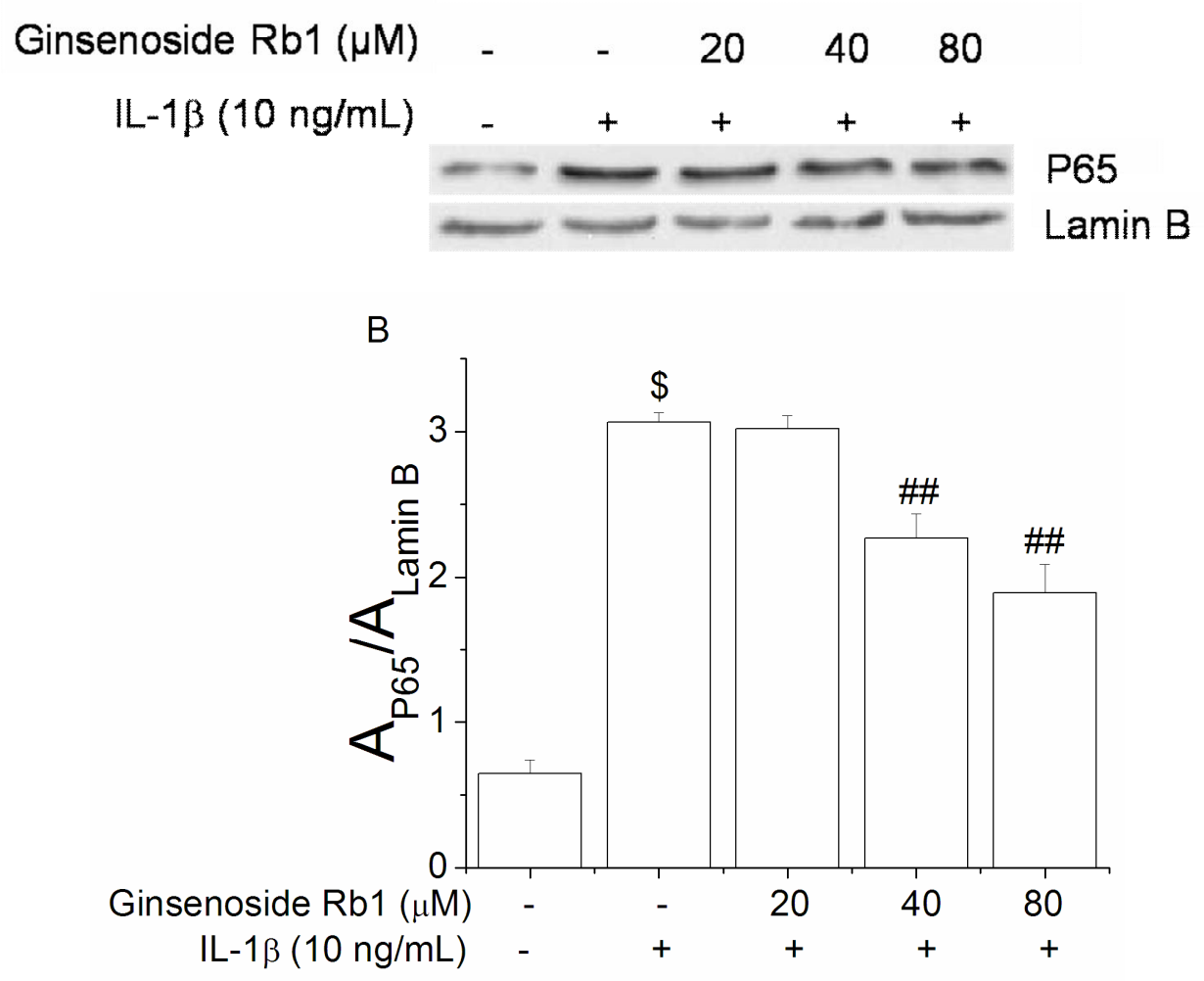

Figure 4: Effect of ginsenoside Rb1 on nuclear translocation of NF-KB p65 in IL-1ß-induced SW1353 cells. SW1353 cells were pre-treated with ginsenoside Rb1 $(20,40,80 \mu \mathrm{M})$ for $2 \mathrm{~h}$ and stimulated with $10 \mathrm{ng} / \mathrm{mL} \mathrm{IL}-1 \beta$ for $1 \mathrm{~h}$. (A) NF-kB p65 protein in nucleus was detected by Western blot; (B) Bar graphs showed quantitative evaluation of NF-kB p65 bands by densitometry. Three independent experiments performed in duplicate. Values are mean $\pm S D ;{ }^{\$} p<0.01$ vs. media alone-treated group; ${ }^{\# \#} p<0.01$ vs. IL-1 $\beta$ alone-treated group

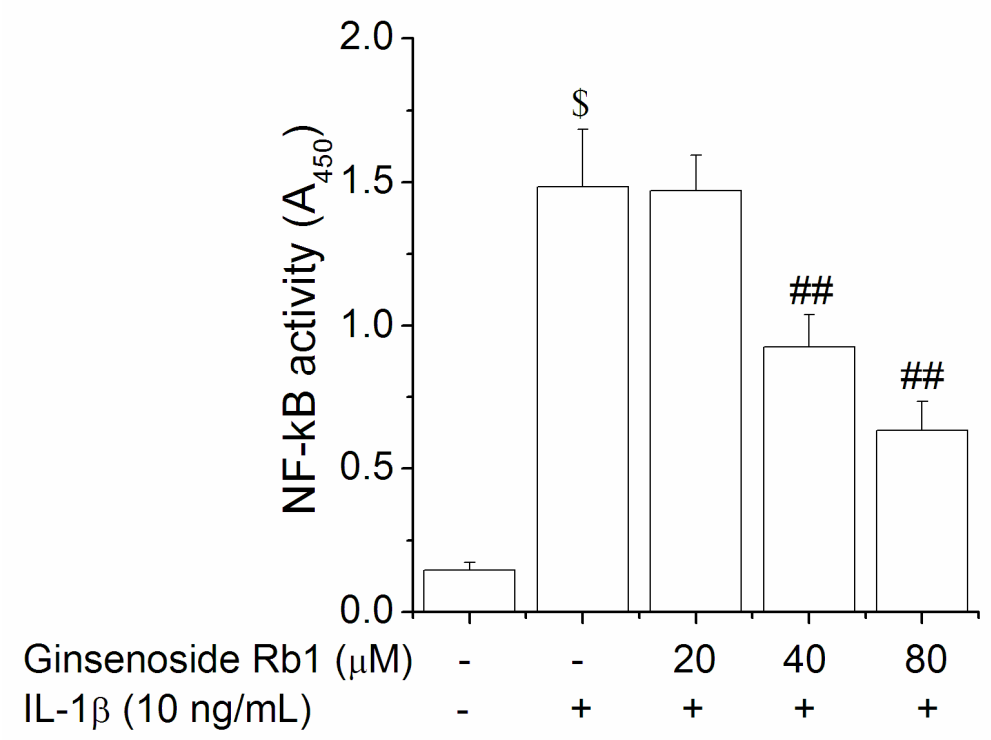

Figure 5: Effect of ginsenoside Rb1 on DNA binding activity of NF-KB in IL-1 $\beta$-induced SW1353 cells. SW1353 cells were pre-treated with ginsenoside Rb1 $(20,40,80 \mu \mathrm{M})$ for $2 \mathrm{~h}$ and stimulated with $10 \mathrm{ng} / \mathrm{mL} \mathrm{IL}-1 \beta$ for $1 \mathrm{~h}$. Nuclear protein extracts were used to measure DNA binding activity of NF-KB complex with the Trans AM ${ }^{\mathrm{TM}} \mathrm{kit}^{\mathrm{m}}$ for p65. Three independent experiments performed in duplicate; values are mean $\pm \mathrm{SD} ;{ }^{\$} p<0.01$ vs. media alonetreated group; ${ }^{\#} p<0.01$ vs. IL-1 $\beta$ alone-treated group 


\section{DISCUSSION}

In the present study, we demonstrated that ginsenoside $\mathrm{Rb} 1$, an active constituent in ginseng, could inhibit NO production in IL-1 $\beta$ induced SW1353 chondrocytes in a concentration-dependent manner. Meanwhile, concentrations of ginsenoside $\mathrm{Rb} 1$ used in this study were not cytotoxic to SW1353 cells, suggesting that this result was not due to reduced cell viability. Interestingly, evidence has verified that ginsenoside $\mathrm{Rb} 1$ can increase $\mathrm{NO}$ production in endothelial cells. Ginsenoside Rb1 prevented homocysteine-induced endothelial dysfunction by upregulating endothelial nitric oxide synthase (eNOS)/NO production in human umbilical vein endothelial cells [15]. It was also shown to abate homocysteine-induced endothelial dysfunction by increasing NO production and eNOS phosphorylation via PI3K/Akt activation and PKC inhibition [16]. Ginsenoside $\mathrm{Rb} 1$ had protective effects on oxLDL-injuring human vascular endothelial cells by increasing NO production and eNOS mRNA expressions [14]. Although these results appear to contradict our results, it is possible that regulation of NOS/NO signal by ginsenoside Rb1 varies in different pathological conditions.

Three isoforms of NOS have been identified, including inducible (iNOS), endothelial (eNOS) or neuronal NOS (nNOS) [17]. While the latter two are constitutively expressed, iNOS is expressed following stimulation with a variety of inflammatory agents such as endotoxins (LPS) or cytokines including IL-1 $\beta$ and TNF- $\alpha$. Under inflammatory conditions, iNOS is the key enzyme responsible for NO production [18]. Since we demonstrated the inhibitory effect of ginsenoside Rb1 on NO generation, we subsequently investigated the effect of ginsenoside $\mathrm{Rb} 1$ on iNOS protein expression in IL-1 $\beta$-induced SW1353 cells. Consistent with the inhibitory effect on $\mathrm{NO}$ production, ginsenoside Rb1 was found to attenuate IL-1 $\beta$-induced iNOS protein expression in SW1353 cells in a concentrationdependent manner. Especially, the inhibitory rate of ginsenoside Rb1 at $80 \mu \mathrm{M}$ exceeded $50 \%$. This data indicated that regulation of iNOS/NO signal in chondrocytes was the principle mechanism of anti-inflammation by ginsenoside $\mathrm{Rb} 1$.

NF-KB activation has been implicated as a major mechanism for iNOS expression in IL-1 $\beta$-induced chondrocytes [19]. NF-kB activation requires three key steps including degradation of IKBa, nuclear translocation of NF-KB p65 and DNA binding of the NF-KB complex [20]. Numerous anti-inflammatory agents have been found to regulate NF-KB activation by interfering with one or more of these steps [21-24]. In this study, we found that ginsenoside $\mathrm{Rb} 1$ inhibited IKBa degradation, as well as decreased levels of p65 protein in the nucleus of IL-1 $\beta$-induced SW1353 cells. These data suggested that ginsenoside $\mathrm{Rb} 1$ arrests the IL-1 $\beta$-induced nuclear translocation of NF-KB p65. We also found that ginsenoside $\mathrm{Rb} 1$ inhibited the DNA binding activity of NF-kB complex. These results indicated that ginsenoside Rb1 can inhibit NF-KB activation through multiple mechanisms.

It has a long history of use in TCM to alleviate symptoms and delay the pathological development of $\mathrm{OA}$, and ginseng is one of the most popular Chinese materia medica for OA treatment in TCM in China [25]. However, the mechanism by which the active components of ginseng exert their effects on $\mathrm{OA}$ are not clear. Our results show that ginsenoside $\mathrm{Rb} 1$ can inhibit NO production in IL-1 $\beta$-induced chondrocytes by its downregulating iNOS protein expression. This effect is attributed to the repression of NF-kB by stabilizing $I k B \alpha$ degradation, inhibiting nuclear translocation of p65 and impairing DNA binding activity of NF-KB complex. Together our findings may in part explain the mechanisms by which ginseng exerts its beneficial effects in OA.

\section{CONCLUSION}

Ginsenoside Rb1 can significantly decrease NO production and iNOS protein expression in IL-1 $\beta$ induced SW1353 cells. This is accomplished through repression of NF-KB activation via multiple mechanisms. These results suggest that ginsenoside $\mathrm{Rb} 1$ is a potential anti-NO agent for $O A$ treatment, and reveals the underlying mechanism of the beneficial effect of ginseng in OA treatment in TCM. Subsequent studies are necessary to examine the effect of ginsenoside $\mathrm{Rb} 1$ in animal models of OA.

\section{ACKNOWLEDGEMENT}

This work was supported by a grant from Chongqing Health Bureau (ref. no. 2011266).

\section{REFERENCES}

1. Vuolteenaho K, Moilanen T, Knowles RG, Moilanen E. The role of nitric oxide in osteoarthritis. Scand $J$ Rheumatol 2007; 36: 247-258.

2. Charles IG, Palmer RM, Hickery MS, Bayliss MT, Chubb AP, Hall VS, Moss DW, Moncada S. Cloning, characterization, and expression of a cDNA encoding 
an inducible nitric oxide synthase from the human chondrocyte. Proc Natl Acad Sci U S A 1993; 90: 11419-11423.

3. Spreng $D$, Sigrist $N$, Schweighauser $A$, Busato $A$, Schawalder $P$. Endogenous nitric oxide production in canine osteoarthritis: Detection in urine, serum, and synovial fluid specimens. Vet Surg 2001; 30: 191199.

4. Grabowski PS, Wright PK, Van 't Hof RJ, Helfrich $M H$, Ohshima $H$, Ralston SH. Immunolocalization of inducible nitric oxide synthase in synovium and cartilage in rheumatoid arthritis and osteoarthritis. $\mathrm{Br}$ J Rheumatol 1997; 36: 651-655.

5. Wang S, Yan L, Wesley RA, Danner RL. Nitric oxide increases tumor necrosis factor production in differentiated U937 cells by decreasing cyclic AMP. J Biol Chem 1997; 272: 5959-5965.

6. Murrell $G A$, Jang $D$, Williams RJ. Nitric oxide activates metalloprotease enzymes in articular cartilage. Biochem Biophys Res Commun 1995; 206: 15-21.

7. Cao M, Westerhausen-Larson A, Niyibizi C, Kavalkovich K, Georgescu HI, Rizzo CF, Hebda PA, StefanovicRacic $\mathrm{M}$, Evans $\mathrm{CH}$. Nitric oxide inhibits the synthesis of type-ll collagen without altering Col2A1 mRNA abundance: prolyl hydroxylase as a possible target. Biochem J 1997; 324 (1): 305-310.

8. Brown KD, Claudio E, Siebenlist U. The roles of the classical and alternative nuclear factor-kappaB pathways: potential implications for autoimmunity and rheumatoid arthritis. Arthritis Res Ther 2008; 10: 212.

9. Pasparakis M. Regulation of tissue homeostasis by NFkappaB signalling: implications for inflammatory diseases. Nat Rev Immunol 2009; 9: 778-788.

10. Ruan Y, Yao L, Zhang B, Zhang $S$, Guo J. Antiinflammatory effects of Neurotoxin-Nna, a peptide separated from the venom of Naja naja atra. BMC Complement Altern Med 2013; 13: 86.

11. Hunter DJ. Pharmacologic therapy for osteoarthritis--the era of disease modification. Nat Rev Rheumatol 2011; 7: 13-22.

12. Cao Y, Zhan H, Pang J, Li F, Xu S, Gao J, Xu Z, Li G, Liu $T$, Guo $C$ et al. Individually integrated traditional Chinese medicine approach in the management of knee osteoarthritis: study protocol for a randomized controlled trial. Trials 2011; 12: 160.

13. Joh $E H$, Lee IA, Jung $I H$, Kim DH. Ginsenoside Rb1 and its metabolite compound $K$ inhibit IRAK-1 activation-the key step of inflammation. Biochem Pharmacol 2011; 82: 278-286.

14. He F, Guo R, Wu SL, Sun M, Li M. Protective effects of ginsenoside $R b 1$ on human umbilical vein endothelial cells in vitro. J Cardiovasc Pharmacol 2007; 50: 314320.
15. Xu Z, Lan T, Wu W, Wu Y. The effects of ginsenoside $R b 1$ on endothelial damage and ghrelin expression induced by hyperhomocysteine. J Vasc Surg 2011; 53: 156-164.

16. Lan TH, Xu ZW, Wang Z, Wu YL, Wu WK, Tan HM. Ginsenoside Rb1 prevents homocysteine-induced endothelial dysfunction via PI3K/Akt activation and PKC inhibition. Biochem Pharmacol 2011; 82: 148155.

17. Kobayashi $Y$. The regulatory role of nitric oxide in proinflammatory cytokine expression during the induction and resolution of inflammation. $J$ Leukoc Biol 2010; 88: 1157-1162.

18. Abramson SB, Attur M, Amin AR, Clancy R. Nitric oxide and inflammatory mediators in the perpetuation of osteoarthritis. Curr Rheumatol Rep 2001; 3: 535-541.

19. Akhtar N, Miller MJ, Haqqi TM. Effect of a Herbal-Leucine mix on the IL-1beta-induced cartilage degradation and inflammatory gene expression in human chondrocytes. BMC Complement Altern Med 2011; 11: 66 .

20. Renner F, Schmitz ML. Autoregulatory feedback loops terminating the NF-kappaB response. Trends Biochem Sci 2009; 34: 128-135.

21. Jomphe C, Gabriac M, Hale TM, Heroux L, Trudeau LE, Deblois $D$, Montell E, Verges $J$, $d u$ Souich $P$. Chondroitin sulfate inhibits the nuclear translocation of nuclear factor-kappaB in interleukin-1betastimulated chondrocytes. Basic Clin Pharmacol Toxicol 2008; 102: 59-65.

22. Canas N, Gorina R, Planas AM, Verges J, Montell E, Garcia AG, Lopez MG. Chondroitin sulfate inhibits lipopolysaccharide-induced inflammation in rat astrocytes by preventing nuclear factor kappa B activation. Neuroscience 2010; 167: 872-879.

23. Shin HM, Byung Hak K, Eun Yong C, Jung SH, Yeong Shik K, Kyung Rak M, Kim Y. Suppressive effect of novel aromatic diamine compound on nuclear factorkappaB-dependent expression of inducible nitric oxide synthase in macrophages. Eur J Pharmacol 2005; 521: 1-8.

24. Chiang YM, Lo CP, Chen YP, Wang SY, Yang NS, Kuo $Y H$, Shyur LF. Ethyl caffeate suppresses NF-kappaB activation and its downstream inflammatory mediators, iNOS, COX-2, and PGE2 in vitro or in mouse skin. Br J Pharmacol 2005; 146: 352-363.

25. Jia L, Zhao $Y$, Liang XJ. Current evaluation of the millennium phytomedicine- ginseng (II): Collected chemical entities, modern pharmacology, and clinical applications emanated from traditional Chinese medicine. Curr Med Chem 2009; 16: 2924-2942. 